\title{
EXTENSIONS OF USAGE OF A PRONOUN ${ }^{1}$
}

\section{Louise Pound}

\section{UNIVERSITY OF NEBRASKA}

[This article treats briefly, in the chronology of their appearance, the substantive uses of the pronoun of the third person neuter: the English and American game usage, two American colloquial or dialectal usages, and the newest usage, emerging from Hollywood, with its adjectival and nominal derivatives.]

The English pronoun of the third person neuter, it, has established itself as a substantive in various meanings, some of which are so widely current as to augur for them considerable vitality. An enumeration of these substantive uses in American English yields the followingapproximately, I think, in the order of their appearance.

1. In game usage the person that is termed it has a specialized function making him the protagonist for the time being, as in the games of 'tag' and 'drop the handkerchief.' This usage of the word came to America, no doubt, along with the games employing it. Certainly 'tag' and 'drop the handkerchief' are not of indigenous origin but are imported. The Oxford Dictionary (vol. V. 1901) does not enter the game usage of the word, but it is included in Wright's English Dialect Dictionary ("It . . . In games the 'he' or central figure, the person who has the innings"), and in the larger American dictionaries.

2. Deriving perhaps from game usage is the American slang or colloquial usage appearing in expressions like 'She thinks she's it,' 'That officer thinks he's it,' the implication being that the person in question thinks him or herself of especial importance. A social-literary club of my acquaintance once voted to have no officer save a single supreme one called 'It,' a permanent controlling officer who sometimes appointed a 'Vice-It' or 'Sub-It' to officiate during her absence. According to a definition given me by an academic devotee of this substantive, a person who thinks himself 'it' believes that he is the 'king pin' or 'head potentate' of his circle.

1 This paper was read at the sixth annual meeting of the Linguistic Society of America in Cleveland, Ohio, on December 31, 1929. 
This colloquial usage is not entered in dictionaries. It does not appear in the Oxford Dictionary nor in the larger American dictionaries. Wright's English Dialect Dictionary does not cite it as existent in England. It seems to be American, and of twentieth century establishment. During the Russo-Japanese war, when the addition of the suffix -ski was in vogue for jocose formations, one heard occasionally on college campuses sentences like 'She thinks she's Madame Ittski,' 'There go Mr. Ittski and Mr. Smartski.'

3. Another widely current usage of the pronoun gives it the meaning of stupid person, fool, or rustic. In this sense the pronoun is sometimes capitalized: 'Such an It', 'The big It sneezed in my face,' 'The It didn't know enough to come in out of the rain.' This usage is not recorded in dictionaries of the standard language. It is not mentioned in the English historical dictionary. Wright enters it as a term of contempt and as often used of infants, but not in the American way. Compare: 'Some fooak says id as if they were tawkin' abeawt a hinsekt when they meean their husband, child, wife or parent,' 'What a hawhaw it is to call itsen a parson.'

4. Last and most recent is the use launched by Elinor Glyn a few years ago (1926) in a film entitled 'It', starring Clara Bow. This use quite certainly emerged from America-from Hollywood. Mrs. Glyn meant by it personal magnetism or attractiveness. In this sense the word was quickly taken up by cinema enthusiasts, by journalists, and by young people, and it is now familiar everywhere.

Further, this usage has its own extensions. The adjective itty followed at the heels of Mrs. Glyn's new substantive. Sentences like these may be gathered from oral usage, from film journals, or from advertisements: 'She is a very itty actress,' 'That actress is not so itty as she thinks.' Often the adjective is compared: 'Buddy Rogers is ittier than other youths of the screen', 'Clara Bow is the ittiest actress of them all.' A compound itfulness was used in a motion picture magazine of the date of November, 1929: 'There they stood [the hero and heroine], the very picture of itfulness.' 